\title{
A Study on Farmers' Perception and Preference in Subscribing to Drought-Index Crop Insurance in the Northern Region of Ghana
}

\author{
Stephen A. Abugri \\ Department of Agricultural and Resource Economics, University for Development Studies, Tamale, Ghana \\ E-mail: stephenabugri@gmail.com
}

\begin{abstract}
Climate variability has become a challenge on the livelihoods of smallholder farmers in Northern Ghana and its impacts becoming severer and as a result, crop insurance has since been seen as the best remedy. Data was obtained from 315 farmers in 15 communities of Tolon and Kumbungu districts and Savelugu-Nanton municipality using multistage sampling procedure. The data collected was used in analyzing maize farmers' perceptions as well as preferences in subscribing to crop drought-index insurance. A Likert Scale was used to analyze farmers' perception about crop index insurance whiles the Multinomial Logistic Regression model analyzed farmers' preference. Most of the respondents declared that crop index insurance is a production risk management tool that can be used to combat the negative effects of climate change on their farms and livelihood as a whole. However, it was concluded that, the most preferred crop insurance package is the public crop insurance package and government subsidy was the highest rank coping strategy. It is therefore imperative that Government role out crop insurance packages and subsidizes the initial stages of crop insurance programs to encourage participation by farmers to effectively mitigate against climate change.
\end{abstract}

Keywords: climate change, perception, drought-index insurance, northern region

\section{Introduction}

Notwithstanding agriculture being an important source of income growth and a potential source of investment opportunities, inherent risks have been an integral part of the agriculture sector. Rainfall variability and other weatherrelated hazards are an important component of risk that confront farmers due to high association that exist between climatic factors and performance of agricultural sector. Given the over-dependence of smallholder farmers on rain-fed agriculture, climate variability and change is rapidly frightening sustained agricultural productivity, food security as well as economic development. The two major risk associated with agriculture are price risks caused by potential volatility in prices and production risk resulting from uncertainty about the levels of production with no evidence of any decrease in the near future; instead, Iturrioz ${ }^{[1]}$ indicated that, it is likely that these major risks will increase.

"Agricultural production, including access to food, in many African countries and regions is projected to be severely compromised by climate variability and change. The area suitable for agriculture, the length of growing seasons and yield potential, particularly along the margins of semi-arid and arid areas, are expected to decrease. In some countries, yields from rain-fed agriculture could be reduced by up to $50 \%$ by $2020^{\prime \prime}{ }^{[2]}$. To help reverse this worsening effects of climate change on agriculture, it has been concluded that much greater emphasis will have to be given to increasing the productivity of global rain-fed agriculture which currently provides about $60 \%$ of the world's food. This is especially true in sub-Saharan Africa where nearly $90 \%$ of staple food production will continue to come from rain-fed farming systems ${ }^{[3]}$.

In general, insurance is a form of risk management used to hedge against a contingent loss. The traditional definition is the equitable transfer of a risk of loss from one entity to another in exchange for a premium or a guaranteed and quantifiable small loss to prevent a large and possibly devastating loss. Agricultural insurance is a special line of property insurance applied to agricultural firms and production. Agricultural insurance is not limited to crop insurance, it also applies to livestock, bloodstock, forestry, aquaculture, and greenhouses ${ }^{[1]}$. Crop insurance is a government course that provides protection to farmers against loss of crops on the account of natural calamities, pest and disease and other related perils or threats ${ }^{[4]}$.

Insurance is one of the best approaches used in several countries to share production risks ${ }^{[5]}$. Crop Insurance is an 
insurance arrangement pointing at mitigating the financial losses suffered by farmers due to damage and destruction of their crops as a result of many production risks ${ }^{[6]}$.

Over the years, financial and technological innovations have made insurance more affordable. One innovation is index-based crop insurance, which allows individual farmers to protect themselves against agricultural production risk by paying out when an independently observable trigger (such as the level of rainfall at a local weather station or data on output in a given area) shows that an insurable event has occurred. Although literature suggests that agricultural insurance has the potential to unlock other key services in the agricultural sector that are important in augmenting productivity, conservative indemnity-based type of crop insurance is inadequate to insure smallholders because of the associated ethical hazard and antagonistic selection weaknesses and the bewildering insurance administration costs especially when dealing with over-dispersed population of smallholder farmers ${ }^{[7]}$.

No matter the type and kind of policy introduced, farmers as well as any other person may have their own impression about the introduced policy of which crop insurance is not an exception. It is alleged that famers in sub-Saharan Africa perceives crop insurance to be relatively complex and do not always trust the validity of the simulated yields and smallholders did not value insurance, perhaps because of the lack of collateral and the lender's inability to sanction defaulting borrowers whiles providing implicit insurance.

The Ghana GAIP's Drought Index Insurance (DII) program was introduced in 2011, this program relies on climate and harvest indicators to envisage yield losses for a number of cereal crops such maize, millet and sorghum. This programme is a protective tool for smallholder farmers' income by helping them get access to insurance contracts and credit facilities. It is designed to alleviate crop yield losses resulting from drought, and aims at boosting the confidence of the financial institutions in lending out agricultural and production loans to smallholder farmers.

With increasing evidence showing that the DII scheme is an imperative agriculture production risk mitigation strategy, the subscription rate of intended insurance packages under the DII scheme in Ghana is still low ${ }^{[8]}$. This is accredited to the fact that farmers are credit reserved, price the present over the future, value certainty, or perceive the benefits of the insurance as ambiguous and the low level of farmer's awareness of existing insurance packages and how they operate. The few farmers with knowledge of the existing insurance schemes tend to perceive the payable premiums as not sustainably reasonable. In the face of climate variability and change, the DII scheme does not only serves as a mitigation strategy to climate change but that, the DII also employed increasingly and successfully as an initiative for building climate change flexibility among farmers particularly in the semi-arid savannah zone of Northern Ghana.

Considering the advantages of weather-indexed crop insurance especially is that in the event of yield failure resulting from natural manifestations beyond farmers' control, crop insurance will help protect the farmer against total production and income losses. Crop insurance is also a substitute source of farm revenue to help reduce the impact of the incurred farmer losses ${ }^{[9]}$.

With limited attempts to investigate the perceptions and preferences of smallholder farmers on crop insurance, this study seeks to bring to light the present situation of maize farmers' ideologies of crop insurance in the northern region of Ghana as a mitigation strategy to fight against the risk associated with climate change. Motivated by the need to fill the above mentioned empirical knowledge gap in the Northern Region of Ghana, the study on which this paper is based seeks to analyze farmers' perception about crop insurance in their decision to subscribe to certified crop insurance schemes and their preference heterogeneity for choosing different packages of crop insurance premiums under GAIP ${ }^{[10]}$. The goal is to help in the design of attractive crop insurance packages to increase the uptake by and lending from financial institutions to smallholder farmers.

\section{Study area and dataset}

The study was conducted in three areas located in the semi-arid Guinea Savannah Zone (GSZ) of Northern Ghana. These are the Tolon and Kumbungu districts and Savelugu municipal which formed part the pilot districts of the GAIP's crop insurance scheme. The study used the multistage approach, the districts were purposively sampled and whiles communities and respondents were sampled by means of the simple random sampling procedure.

The area has an estimated population of about 250000 people with majority been small holder farmers. Rain-fed, semi-subsistence agriculture comprising "homestead farms" dominated by maize and sorghum systems with mixtures of cowpea, and vegetables; and "bush farms" dominated by rice, groundnuts and other monocrops; and the rearing of livestock is the most predominant source of livelihood. Maize is the dominant crop in all these three areas. Rainfall in the study area is mono-modal in distribution and ranges from $900-1100 \mathrm{~mm}$, and lasts from 71-78 days between May-October annually. 
An exploratory survey was conducted in the three areas for the purpose of collecting the above relevant data needed for applying the chosen stated Likert Scale and Multinomial Logistic Model (MLM) for the analysis. The survey was conducted using face-to-face interviews with farm household heads. The analysis is conducted on a total of 315 farmers (i.e.105 respondents / area). The data pertains to the 2018-2019 agricultural production year.

\section{Data analysis}

\subsection{The likert scale}

In time past, numerous methods were used to measure character and personality traits ${ }^{[11]}$. The difficulty of measuring attitudes, character, and personality traits lies in how these traits can be transferred into quantitative measure for data analysis purposes. The recent popularity of qualitative research techniques has relieved some of the burden associated with this dilemma; even though many social scientists still rely on quantitative measures of attitudes, character and personality traits. In response to the difficulty of measuring character and personality traits, Likert ${ }^{[11]}$ developed a procedure for measuring attitudinal scales.

The original Likert scale used a series of questions with five response alternatives: strongly agree (5), agree (4), neutral (3), disagree (2), and strongly disagree (1). This research used the original Likert scale because it gives a wider range of responses than the triple scale. He combined the responses from the series of questions to create an attitudinal measurement scale. His data analysis was based on the composite score from the series of questions that represented the attitudinal scale. He did not analyze individual questions. While Likert used a five-point scale, other variations of his response alternatives are appropriate, including the deletion of the neutral response ${ }^{[12]}$.

With the Likert scale, a scale is created as a simple sum of questionnaire responses over the full range of scale. In so doing, Likert scaling assumes the distances on each items are equal. All items are assumed to be replications of each other or items are considered to be parallel instruments.

\subsection{Multinomial Logistic Model (MLM)}

Multinomial Logistic Regression model is a logistic model having a dependent variable with more than two levels ${ }^{[13]}$. The choice of this method is based on the fact that the preference of farmers (dependent variable) is a categorical variable which takes six (6) levels $(1,2,3,4,5$ and 6). This classification is based on the fact that crop insurance comes in different packages. This eliciting technique has been used is a multi-item scale by Pennings and Garcia ${ }^{[14]}$.

In this study, 1 is the crop index insurance package that covers all crops, 2 is the crop index insurance package with government subsidy, 3 is the crop index insurance package with reduced premium, 4 is a private crop index insurance package, 5 is the crop index insurance package that covers only maize farmers and 6 is the crop index insurance package which is free. The package with government subsidy was taken as the reference package. The model was used to analyze objective 2 in identifying the socio-economic characteristics responsible for farmers' preference in choosing different packages among alternative schemes.

According to Ayinde et al. ${ }^{[15]}$, the probability that the $i^{\text {th }}$ farmer chooses the $j^{\text {th }}$ insurance package reduces to:

$$
P_{i j}=\frac{e^{\beta_{j} X_{i}}}{\sum_{k=j} e^{\beta_{k} X_{i}}}
$$

According to Maddala ${ }^{[16]}$, the model makes the choice probabilities on individual's characteristics of the agents. Following Maddala ${ }^{[17]}$ and Babcock et al. ${ }^{[18]}$, the basic model is written as:

$$
P_{i j}=\frac{e^{\beta_{j} X_{i}}}{\sum_{k=0}^{j} e^{\beta_{j} X_{i}}}
$$

Where $i=1,2 \ldots n$ Variables; $k=1,2 \ldots j$ choices and $\beta_{j}=$ a vector of parameters that relates to $X_{i}$ 's to the probability of choosing the $j^{\text {th }}$ package where there are $\mathrm{j}+1$ packages. 


\subsection{Normalization of the model}

The summation of the probability for the six (6) packages must be equal to unity. This calls for a normalization of the equations in the model. The common rule is to set one of the parameter vectors equal to zero ${ }^{[19]}$. Hence for number of choices, only $v-1$ distinct parameters can be identified and estimated. In this study, $k$ is six (6) choices and five (5) distinct parameters were identified and estimated.

Based on equation (2), the probability of being in the reference package (government subsidy insurance package) with parameter vectors equal zero is

$$
P_{i 0}=\frac{1}{1+\sum_{k=j} e^{\beta_{k} X_{i}}}
$$

Similarly, the probability of being in each of the other $j$ groups is

$$
P_{i j}=\frac{e^{\beta_{j} X_{i}}}{1+\sum_{k=j} e^{\beta_{k} X_{i}}}
$$

Dividing equation (3) by (4) gives

$$
\frac{P_{i j}}{P_{i 0}}=e^{\beta_{j} X_{i}}
$$

This denotes the relative probability of each choice group to the probability of the reference choice.

Hence, the estimated coefficients for each choice reflect the effects of $X_{i}$ 's on the likelihood of a farmer choosing the alternative package relative to the reference package. The logarithm of the odd ratio in equation (5) to the base gives the estimating equation.

$$
\operatorname{Ln}\left[\frac{P_{i j}}{P_{i 0}}\right]=\beta_{j} X_{i}
$$

Equation 6 implies that, $j \log$ odds ratio can be computed ${ }^{[20]}$. However, following Hill ${ }^{[21]}$, the coefficients of the reference group may be recovered by using the formula:

$$
\beta_{v}=-\left[\beta_{1}+\beta_{2}+\cdots+\beta_{v-1}\right]
$$

The software package used for this data analysis is StataSE version 14 with all unrepresentative data (outliers) eliminated and multicollinearity among independent variables well tested. 
Table 1. Variables and their measurements

\begin{tabular}{|c|c|c|}
\hline Independent variables & Description & Measurement \\
\hline Sex & Sex of respondent & $\begin{array}{c}\text { Dummy, } \\
\text { Male }=1, \\
\text { Female }=0\end{array}$ \\
\hline Age & Age of respondent & $\begin{array}{c}\text { Continuous, } \\
\text { Years }\end{array}$ \\
\hline Educational level & Number of years in school & $\begin{array}{c}\text { Indicator, } \\
\text { No Education =0 } \\
\text { Primary }=1 \\
\text { JHS }=2 \\
\text { SHS }=3 \\
\text { Tertiary }=4\end{array}$ \\
\hline $\begin{array}{l}\text { Crop insurance } \\
\text { awareness }\end{array}$ & Respondent awareness Level of crop indexinsurance & $\begin{array}{c}\text { Dummy, } \\
\text { Aware }=1, \\
\text { Not aware }=0\end{array}$ \\
\hline Household size & Number of people living under your care & $\begin{array}{l}\text { Continuous, } \\
\text { Number }\end{array}$ \\
\hline Farm risk level & Level of risk a farmer is expose to & $\begin{array}{c}\text { Indicator, } \\
\text { High }=1 \\
\text { Medium }=2 \\
\text { Low }=0\end{array}$ \\
\hline Damage caused & Level of damage course by an event & $\begin{array}{c}\text { Indicator, } \\
\text { High }=1 \\
\text { Medium }=2 \\
\text { Low }=0\end{array}$ \\
\hline Regular payment & Ability to pay the insurance premium annually & $\begin{array}{l}\text { Dummy, } \\
\text { Yes }=1, \\
\text { No }=0\end{array}$ \\
\hline Non-farm income & Level of farmer income from other non-farm activities & $\begin{array}{c}\text { Continuous, } \\
\text { GHS }\end{array}$ \\
\hline Understand insurance & Does farming understand the concept of crop insurance & $\begin{array}{l}\text { Dummy, } \\
\text { Yes }=1 \\
\text { No }=0\end{array}$ \\
\hline Why insure farm & Why does a farmer need to insure the farm & $\begin{array}{c}\text { Indicator, } \\
\text { Farm at risk }=0 \\
\text { Reduce financial risk }=1 \\
\text { Increase production }=2 \\
\text { Others }=3\end{array}$ \\
\hline Farm size & Size of farmland & $\begin{array}{l}\text { Continuous, } \\
\text { Acres }\end{array}$ \\
\hline
\end{tabular}

\section{Results and discussion}

\subsection{Farmers' perception about crop insurance}

Farmers were asked about their perception about crop drought-index insurance. This was done by the ranking of certain predetermined factors read to respondents to rank on a Likert scale of 1 to 5 in the scale strongly agree (5), agree (4), neutral (3), disagree (2), and strongly disagree (1), a summary statistics of the responses was analyzed as presented below in Table 2.

The most perceived factor was identified using the summation means factor where the factor with the highest mean is the most perceived factor with reference to the coding above. Farmers are more concern to the production risk of their farming activities and therefore majority of the respondents declared that crop index insurance is a production risk management tool that can be used to curb the negative effects of climate change on their farms and livelihood as a whole.

This implies that, there is no doubt in the mind that maize farmers in the northern region will and are ready to insure their farms with crop index insurance to fight against production risk posed by climate change. This finding is consistent with the observation made by IFAD and WFP ${ }^{[22]}$ that crop insurance has been advocated as a direct way of assisting small scale farmers facing production risks with the expectation that such insurance would lead to less risk-averse behavior and to a more efficient use of scarce productive resources by farmers.

Second to production risk management is that farmers believe that crop index insurance will reduce their financial risk as well as help them increase their production. All these are positive perception by maize farmers in the northern region and therefore there is the need for insurance companies to reach out to them. Farmers also disagree with the fact that crop index insurance has no benefit and therefore ranked it last as shown in the Table 1 below. The results supports Bhende ${ }^{[23]}$ who concluded that if properly designed and implemented crop insurance program will protect the numerous vulnerable small and marginal farmers from hardship, bring in stability in the farm incomes and increase the farm production. The order of perception as realized by respondents is summarized in the Table 2 below. 
Table 2. Ranked perceived factors affecting farmers' crop insurance decision

\begin{tabular}{|c|c|c|c|c|}
\hline Perception & Obs & Std. Dev. & Mean & Rank \\
\hline No benefit & 315 & 0.73 & 1.76 & 13 \\
\hline Is for only poor farmers & 315 & 1.07 & 1.78 & 12 \\
\hline Meant for NGO farmers & 315 & 1.03 & 1.83 & 11 \\
\hline No need for crop insurance & 315 & 0.88 & 1.84 & 10 \\
\hline Personally not interested & 315 & 0.79 & 1.87 & 9 \\
\hline Meant for large farms & 315 & 1.17 & 2.29 & 8 \\
\hline Meant for $\mathrm{CBO} / \mathrm{FBO}$ & 315 & 0.94 & 2.36 & 7 \\
\hline To exploit us & 315 & 1.02 & 2.45 & 6 \\
\hline No trust & 315 & 1.15 & 2.67 & 5 \\
\hline Very selective & 315 & 1.12 & 2.83 & 4 \\
\hline Increase production & 315 & 1.10 & 3.55 & 3 \\
\hline Reduce financial risks & 315 & 1.04 & 3.56 & 2 \\
\hline Production risk management & 315 & 1.03 & 3.71 & 1 \\
\hline
\end{tabular}

Source: Author's computation, 2019

From the farmers' perception about crop insurance as indicated above, it means that, drought index insurance is an effective strategy to the mitigation of climate change and if implemented appropriately within the broader of agricultural risk management agenda it will help in reducing agricultural producers' financial vulnerability to production losses in the northern region of Ghana.

\subsection{Strategies maize farmers prefer in crop insurance packages}

The business of crop production, however, is inherently risky due to its heavy dependence on unpredictable weather factors. Poor households in Northern Ghana who mostly depend on small-scale and rain fed agriculture for their livelihood face substantial yield and income risks due to climate change and lack of resources with which to absorb shocks of natural and manmade disasters. Consequently, small disruptions in the flow of incomes due to natural and manmade hazards do have serious implications for poor households, hence poor farmers commonly avoid production risk by adopting selfinsurance and informal measures and avoiding investing in potentially profitable but risky ventures. Small-scale, rain fed and resource poor farmers in developing countries are therefore obliged to adopt traditional / informal mechanisms for coping with and managing risks ${ }^{[24]}$.

Thus, reliance on traditional risk coping strategies has the potential to trap poor smallholder farmers in perpetual poverty ${ }^{[25]}$. When farmers anticipate risk of crop loss due to drought, flood, windstorms, bushfire, pest infestation, diseases attack and a plethora of other natural disasters, they tend to reduce risk by minimizing investments in the crop by not applying vital inputs such as fertilizer and pesticides since investment in these inputs increase their loss should the crop fail. Therefore, traditional risk coping can boost the chances of survival of the poor crop farmer to a limited extent as it is not an efficient and sustainable risk management tool.

The research tried to solicit farmers view from a set of coping strategies labelled as, irrigation, personal savings, agricultural insurance, government subsidy and bank loan. About 147 of the respondents representing 46.67\% of the respondent preferred government subsidy as a coping strategy, 98 respondents making $31.11 \%$ of the respondents preferred crop insurance, about 52 respondents representing 16.50\% opted for irrigation whiles 12 and 6 respondents representing $3.81 \%$ and $1.91 \%$ preferred bank loan and personal savings respectively.

This implies that, apart from what maize farmers do in their own way to mitigate climate change effects, majority of them would like to have government subsidy as a mitigating strategy against climate change. Crop insurance is preferred closely after government subsidy and this indicates that farmers are much interested to subscribe to crop insurance if made available to them at affordable premiums in their fight against climate change in the northern region. Crop insurance is a government course that provides protection to farmers against loss of crops on the account of natural calamities, pest and disease and other related perils or threats ${ }^{[4]}$. 


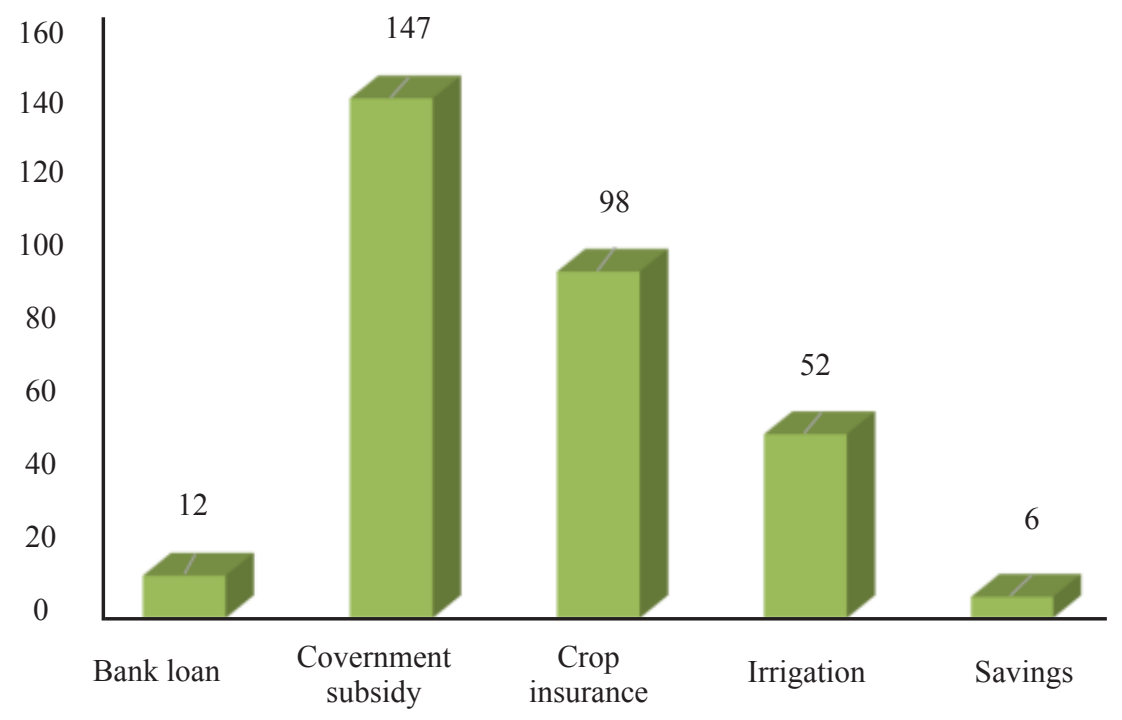

Figure 1. Type of strategy preferred by maize farmers' Source: Author's computation, 2019

\subsection{Results from the multinomial logistic regression of farmers' preferences}

Table 3. Descriptive statistics of variables used in the model

\begin{tabular}{|c|c|c|c|c|c|}
\hline Variable & Observation & Mean & Standard deviation & Minimum & Maximum \\
\hline Damage caused & 315 & 0.70 & 0.89 & 0 & 3 \\
\hline Educational level & 315 & 2.81 & 1.64 & 0 & 5 \\
\hline Household_size & 315 & 13.38 & 5.21 & 3 & 25 \\
\hline Age & 315 & 36.43 & 10.14 & 18 & 70 \\
\hline Farmsize & 315 & 4.61 & 3.46 & 0.5 & 40 \\
\hline Non-farm income & 315 & 1130.32 & 1064.86 & 50 & 7000 \\
\hline Why insure farm & 315 & 1.05 & 1.09 & 0 & 4 \\
\hline Insurance aware & 315 & 0.61 & 0.49 & 0 & 1 \\
\hline Sex & 315 & 0.62 & 0.49 & 0 & 1 \\
\hline Regular payment & 315 & 0.70 & 0.46 & 0 & 1 \\
\hline Under_sd insurance & 315 & 0.38 & 0.49 & 0 & 1 \\
\hline Farm risklevel & 315 & 1.03 & 1.39 & 0 & 3 \\
\hline
\end{tabular}

Source: Author's computation, 2019

The outcome measure in this analysis is preference, crop index insurance package that covers all crops, crop index insurance package with government subsidy, crop index insurance package with reduced premium, private crop index insurance package, crop index insurance package that covers only maize farmers and crop index insurance package which is free.

The package with government subsidy was taken as the reference package, from which the relationships that exists with farmers house hold size, the need to insure farm, whether or not the farmer is aware of crop index insurance, nonfarm income of farmer, farm size, sex of farmer, farmer's age, farmer educational level, the ability of a farmer to pay crop index insurance premium regularly, whether or not the farmer has understood the concept of crop index insurance, the farm risk level of the farmer and the damaged cause by a climate change event in the past. The response variable, preference, is treated categorical under the assumption that the levels of preference status have no natural ordering and Stata automatically chose the referent or based preference which is crop index insurance package with government subsidy.

An important feature of the multinomial logit model is that, it estimates $k-1$ models, where $k$ is the number of levels of the dependent variable. In this instance, Stata, by default, set crop index insurance package with government subsidy as the referent preference and therefore estimated a model for crop index insurance package that covers all crops, crop index 
insurance package with reduced premium, private crop index insurance package, crop index insurance package that covers only maize farmers and crop index insurance package with free premium relative to crop index insurance package with government subsidy.

Therefore, since the parameter estimates are relative to the referent preference, the standard interpretation of the multinomial logit is that, for a unit change in the predictor variable, the logit of the outcome of any other preference relative to the referent preference is expected to change by its respective parameter estimate given that all other variables in the model are held constant.

Marginal effects of the independent variables using the delta method was also estimated, marginal effects refer to the direction and the magnitude of the explanatory variables used in the model at their respective significance levels. It tells us what happens to the dependent variable with a unit change in the explanatory variables ceteris paribus.

Table 4. Results of the Multinomial Logistic Model for all crops relative to government subsidy

\begin{tabular}{|c|c|c|c|c|c|}
\hline Preference & Coef. & Std. Err. & $Z$ & $P>|z|$ & $\mathrm{dy} / \mathrm{dx}$ \\
\hline \multicolumn{6}{|l|}{ For_all_crops } \\
\hline Farmsize & -0.955 & 0.104 & -0.920 & 0.357 & -0.007 \\
\hline Houeshold size & -0.123 & 0.082 & -1.500 & 0.134 & -0.010 \\
\hline Why insure farm & 0.956 & 0.444 & 2.320 & $0.030 * *$ & 0.040 \\
\hline Insurance aware & 2.237 & 0.963 & 2.320 & $0.020 * *$ & 0.166 \\
\hline Non farm income & 0.957 & 0.510 & 1.880 & $0.061^{*}$ & 0.107 \\
\hline Sex & -2.511 & 0.908 & -2.770 & $0.006 * * *$ & -0.170 \\
\hline Age & -0.296 & 0.087 & -3.380 & $0.001 * * *$ & -0.024 \\
\hline Educational level & -0.525 & 0.323 & -1.620 & 0.105 & -0.016 \\
\hline Regular payment & -0.832 & 1.111 & -0.750 & 0.454 & -0.088 \\
\hline Under_sd insurance & -0.663 & 0.976 & -0.680 & 0.497 & 0.173 \\
\hline Farm risk level & -0.681 & 0.358 & -1.900 & $0.057^{*}$ & -0.064 \\
\hline Damage caused & 0.337 & 0.358 & 0.620 & 0.538 & -0.021 \\
\hline _Constant & 12.293 & 3.491 & 3.520 & 0.000 & \\
\hline Government subsidy & Base & Outcome & & & \\
\hline Number of obs $=123$ & LR chi2 (48) & $=185.91$ & Prob & $=0.0000$ & \\
\hline Log likelihood $=-81.4494$ & Pseudo R2 & $=0.533$ & & & \\
\hline$* p=0.1 ; * * p=0.05$ & $* * * p=0.01$ & & & & \\
\hline
\end{tabular}

Source: Author's computation, 2019

\subsection{All crops relative to government subsidy}

From the multinomial logit estimates for crop index insurance that covers all crops relative to government subsidy in Table 4 above, the results indicates that, the variables such as, age and sex very significant at $1 \%$ significance level, why insure farm and insurance awareness are significant at 5\% significance level and farm risk level and nonfarm income are significant at $10 \%$ significance level.

Sex-This is the multinomial logit estimate for a one unit increase in sex for all crops relative to government subsidy given the other variables in the model are held constant. If the sex of a farmer were to increase by one female, the multinomial log-odds for all crops relative to government subsidy would be expected to decrease by 2.511 unit and participation decrease by 0.170 while holding all other variables in the model constant.

Age-This is the multinomial logit estimate for a one unit increase in age for all crops relative to government subsidy given the other variables in the model are held constant. If the age of a farmer were to increase by one more year, the multinomial log-odds for all crops relative to government subsidy would be expected to decrease by 0.525 unit and participation decrease by 0.024 while holding all other variables in the model constant. The impact of a farmer's age can be considered a combination of the effect of farming experience and planning horizon. Although longer experience has a positive effect, young farmers may have longer planning horizons and, hence, may be more likely to invest in agricultural technologies ${ }^{[26,27]}$.

Why insure farm-This is the multinomial logit estimate for a one unit increase in the reason why a farm must be 
insured for all crops relative to government subsidy given the other variables in the model are held constant. If the reason why a farm should be insured were to increase by one which is farm at risk, the multinomial log-odds for all crops relative to government subsidy would be expected to increase by 0.956 unit and participation increase by 0.040 while holding all other variables in the model constant.

Insurance awareness -This is the multinomial logit estimate for a one unit increase in insurance awareness for all crops relative to government subsidy given the other variables in the model are held constant. If insurance awareness of farmers were to increase by one more farmer who becomes aware of crop insurance, the multinomial log-odds for all crops relative to government subsidy would be expected to decrease by 2.237 unit and participation decrease by 0.020 while holding all other variables in the model constant. This results disagrees with Asrat et al. ${ }^{[26]}$ who found that farmers who were aware of the available options for agricultural technology were more receptive to paying for these technologies.

Farm risk level-This is the multinomial logit estimate for a one unit increase in farm risk level for all crops relative to government subsidy given the other variables in the model are held constant. If the risk level of a farm were to increase high, the multinomial log-odds for all crops relative to government subsidy would be expected to decrease by 0.681 unit and participation decrease by 0.064 while holding all other variables in the model constant.

Nonfarm income-This is the multinomial logit estimate for a one unit increase in nonfarm income of a farmer for all crops relative to government subsidy given the other variables in the model are held constant. If the nonfarm income of a farmer were to increase by one Ghanaian cedi (GHS), the multinomial log-odds for all crops relative to government subsidy would be expected to increase by 0.957 unit and participation increase by 0.107 while holding all other variables in the model constant. Karbasi and Kambozia ${ }^{[28]}$, reported that side jobs and high saving by farmers reduce their demand for insurance, but this results disagrees with them.

\subsection{Reduced premium relative to government subsidy}

From the results of the multinomial logit estimates in Table 5 below, farmers who understands the concept of index crop insurance and farmers' age are very significant at $1 \%$ significance level and nonfarm income and sex are significant at $10 \%$ significance level.

Understands the concept of index crop insurance-This is the multinomial logit estimate for a one unit increase in understanding the concept of insurance for all crops relative to government subsidy given the other variables in the model are held constant. If understanding the concept of insurance by farmers were to increase by one more farmer understands the concept of index crop insurance, the multinomial log-odds for all crops relative to government subsidy would be expected to decrease by 3.480 unit and participation decrease by 0.009 while holding all other variables in the model constant.

Age-This is the multinomial logit estimate for a one unit increase in age for all crops relative to government subsidy given the other variables in the model are held constant. If the age of a farmer were to increase by one more year, the multinomial log-odds for all crops relative to government subsidy would be expected to increase by 0.227 unit and participation increase by 0.014 while holding all other variables in the model constant.

Nonfarm income-This is the multinomial logit estimate for a one unit increase in nonfarm income of a farmer for all crops relative to government subsidy given the other variables in the model are held constant. If the nonfarm income of a farmer were to increase by one Ghanaian cedi (GHS), the multinomial log-odds for all crops relative to government subsidy would be expected to decrease by 0.657 unit and participation decrease by 0.021 while holding all other variables in the model constant. This results is consistent with Karbasi and Kambozia ${ }^{[28]}$, who reported that side jobs and high saving by farmers reduce their demand for insurance.

Sex-This is the multinomial logit estimate for a one unit increase in sex for all crops relative to government subsidy given the other variables in the model are held constant. If the sex of a farmer were to increase by one female, the multinomial log-odds for all crops relative to government subsidy would be expected to increase by 1.458 unit and participation increase by 0.053 while holding all other variables in the model constant. 
Table 5. Results of the Multinomial Logistic Model for reduced premium relative to government subsidy

\begin{tabular}{|c|c|c|c|c|c|}
\hline Preference & Coef. & Std. Err. & $Z$ & $P>|z|$ & $\mathrm{dy} / \mathrm{dx}$ \\
\hline \multicolumn{6}{|l|}{ Reduced_premium } \\
\hline Farmsize & -0.247 & -0.240 & 0.103 & 0.811 & -0.010 \\
\hline Houeshold size & 0.043 & 0.064 & 0.670 & 0.501 & -0.000 \\
\hline Why insure farm & 0.347 & 0.300 & 1.160 & 0.248 & 0.000 \\
\hline Insurance aware & -0.792 & 0.737 & -1.070 & 0.283 & -0.059 \\
\hline Non farm income & -0.657 & 0.388 & -1.690 & $0.091^{*}$ & -0.021 \\
\hline Sex & 1.458 & 0.864 & 1.690 & $0.092 *$ & 0.053 \\
\hline Age & 0.227 & 0.064 & 3.570 & $0.000 * * *$ & 0.014 \\
\hline Educational level & -0.073 & 0.222 & -0.330 & 0.744 & 0.032 \\
\hline Regular payment & 1.143 & 0.943 & 1.210 & 0.225 & 0.017 \\
\hline Under_sd insurance & -3.480 & 0.996 & -3.490 & $0.000 * * *$ & -0.009 \\
\hline Farm risklevel & -0.248 & 0.295 & -0.840 & 0.399 & 0.022 \\
\hline Damage caused & 0.162 & 0.375 & 0.430 & 0.666 & -0.027 \\
\hline Constant & -10.082 & 3.142 & -3.21 & 0.001 & \\
\hline Government subsidy & Base & Outcome & & & \\
\hline Number of obs $=123$ & LR chi2 (48) & $=185.91$ & Prob & $=0.0000$ & \\
\hline Log likelihood $=-81.4494$ & Pseudo R2 & $=0.533$ & & & \\
\hline$* p=0.1 ; * * p=0.05$ & $* * * p=0.01$ & & & & \\
\hline
\end{tabular}

Source: Author's computation, 2019

\subsection{Private insurance relative to government subsidy}

For private crop index insurance relative to government subsidy in the Table 6 below, sex and regular payment of insurance premium, non-farm income and age and understanding the concept of crop insurance are all significant at 10\%, 5\% and $1 \%$ significance levels respectively.

Sex-This is the multinomial logit estimate for a one unit increase in sex for all crops relative to government subsidy given the other variables in the model are held constant. If the sex of a farmer were to increase by one female, the multinomial log-odds for all crops relative to government subsidy would be expected to increase by 4.941 unit and participation increase by 0.182 while holding all other variables in the model constant.

Regular payment of insurance premium-This is the multinomial logit estimate for a one unit increase in Regular payment for all crops relative to government subsidy given the other variables in the model are held constant. If the regular payment of insurance premium of farmers were to increase by one more farmer who has ability to regularly pay the insurance premium annually, the multinomial log-odds for all crops relative to government subsidy would be expected to increase by 3.550 unit and participation increase by 0.117 while holding all other variables in the model constant.

Nonfarm income-This is the multinomial logit estimate for a one unit increase in nonfarm income of a farmer for all crops relative to government subsidy given the other variables in the model are held constant. If the nonfarm income of a farmer were to increase by one Ghanaian cedi (GHS), the multinomial log-odds for all crops relative to government subsidy would be expected to decrease by 1.384 unit and participation decrease by 0.029 while holding all other variables in the model constant. Karbasi and Kambozia ${ }^{[28]}$, reported that side jobs and high saving by farmers reduce their demand for insurance.

Age-This is the multinomial logit estimate for a one unit increase in age for all crops relative to government subsidy given the other variables in the model are held constant. If the age of a farmer were to increase by one more year, the multinomial log-odds for all crops relative to government subsidy would be expected to increase by 0.487 unit and participation increase by 0.014 while holding all other variables in the model constant.

Understands the concept of index crop insurance-This is the multinomial logit estimate for a one unit increase in understanding the concept of insurance for all crops relative to government subsidy given the other variables in the model are held constant. If understanding the concept of insurance by farmers were to increase by one more farmer understands the concept of index crop insurance, the multinomial log-odds for all crops relative to government subsidy would be expected to decrease by 8.602 unit and participation decrease by 0.214 while holding all other variables in the model constant. 
Table 6. Results of the Multinomial Logistic Model for private insurance relative to government subsidy

\begin{tabular}{|c|c|c|c|c|c|}
\hline Preference & Coef. & Std. Err. & $Z$ & $P>|z|$ & $\mathrm{dy} / \mathrm{dx}$ \\
\hline \multicolumn{6}{|l|}{ Private_insurance } \\
\hline Farmsize & 0.217 & 0.148 & 1.460 & 0.144 & 0.011 \\
\hline Houeshold size & 0.197 & 0.394 & 1.490 & 0.136 & 0.007 \\
\hline Why insure farm & 0.521 & 0.525 & 0.990 & 0.321 & 0.005 \\
\hline Insurance aware & -1.783 & 1.254 & -0.420 & 0.155 & -0.053 \\
\hline Non farm income & -1.384 & 0.601 & -2.300 & $0.021 * *$ & -0.029 \\
\hline Sex & 4.941 & 2.952 & 1.670 & $0.094 *$ & 0.182 \\
\hline Age & 0.487 & 0.117 & 4.150 & $0.000 * * *$ & 0.014 \\
\hline Educational level & -0.635 & 0.394 & -1.610 & 0.107 & -0.020 \\
\hline Regular payment & 3.550 & 1.966 & 1.810 & $0.071^{*}$ & 0.117 \\
\hline Under_sd insurance & -8.602 & 2.374 & -3.620 & $0.000 * * *$ & -0.214 \\
\hline Farm risklevel & 0.177 & 0.571 & 0.310 & 0.757 & -0.005 \\
\hline Damage caused & 0.407 & 0.663 & 0.610 & 0.540 & -0.001 \\
\hline Constant & -28.226 & 7.592 & -3.720 & 0.000 & \\
\hline Government subsidy & Base & Outcome & & & \\
\hline Number of obs $=123$ & LR chi2 (48) & $=185.91$ & Prob $>$ & $=0.0000$ & \\
\hline Log likelihood $=-81.4494$ & Pseudo R2 & $=0.533$ & & & \\
\hline$* p=0.1 ; * * p=0.05$ & $* * * p=0.01$ & & & & \\
\hline
\end{tabular}

Source: Author's computation, 2019

\subsection{For only male farmers relative to government subsidy}

For only males' crop index insurance relative to government subsidy in Table 7 below, why insure farm is significant at $10 \%$ while climate change damage caused by a climate event is significant at $5 \%$ significance level.

From the results, why insure farm is the multinomial logit estimates for a unit increase in the reason to insure farm for only male farmers crop insurance package relative to crop insurance package with government subsidy given the other variables in the model are held constant. This means that, if a small holder farmer were to increase the reason why to insure the farm by one more reason, which is farm at risk, the multinomial log-odds for only male farmers' crop insurance will increase by 3.733 units while holding while holding all other variables in the model constant. The marginal effect for why insure farm shows that if a farmer were to increase the reasons for why to insure farm, there will be an increase in farmers subscribing to only male insurance by 0.003 relative to insurance with government subsidy.

For damaged caused, this is the multinomial logit estimate for a one unit increase in damaged caused previously due to climate change for only male farmers crop insurance package relative to crop insurance package with government subsidy given the other variables in the model are held constant. If a farm were to increase the damaged caused by one climate change event which is high, the multinomial log-odds for only male farmers crop insurance package relative to crop insurance package with government subsidy would be expected to decrease by 8.249 unit while holding all other variables in the model constant and increase subscription by 0.106 . 
Table 7. Results of the Multinomial Logistic Model for only male farmers relative to government subsidy

\begin{tabular}{|c|c|c|c|c|c|}
\hline Preference & Coef. & Std. Err. & $Z$ & $P>|z|$ & $\mathrm{dy} / \mathrm{dx}$ \\
\hline \multicolumn{6}{|l|}{ Reduced_premium } \\
\hline Farmsize & 0.228 & 1.113 & 0.200 & 0.838 & 0.003 \\
\hline Houeshold size & 0.175 & 0.307 & 0.570 & 0.568 & 0.002 \\
\hline Why insure farm & 3.733 & 2.238 & 1.670 & $0.095^{*}$ & 0.043 \\
\hline Insurance aware & -1.780 & 2.573 & -0.690 & 0.489 & -0.029 \\
\hline Non farm income & -7.188 & 4.558 & -1.580 & 0.115 & -0.095 \\
\hline Sex & -3.510 & 4.817 & -0.730 & 0.466 & -0.047 \\
\hline Age & 0.236 & 0.235 & 1.010 & 0.313 & 0.003 \\
\hline Educational level & -3.504 & 0.239 & -1.570 & 0.118 & -0.043 \\
\hline Regular payment & 3.245 & 5.717 & 0.570 & 0.570 & 0.037 \\
\hline Under_sd insurance & -33.648 & 1741.755 & -0.020 & 0.985 & -0.416 \\
\hline Farm risklevel & 3.209 & 2.282 & 1.410 & 0.160 & 0.045 \\
\hline Damage caused & 8.249 & 4.212 & 1.960 & $0.050 * *$ & 0.106 \\
\hline Constant & -19.389 & 16.971 & -1.140 & 0.253 & \\
\hline Government subsidy & Base & Outcome & & & \\
\hline Number of obs $=123$ & LR chi2 (48) & $=185.91$ & Prob & 0.0000 & \\
\hline Log likelihood $=-81.4494$ & Pseudo R2 & $=0.533$ & & & \\
\hline$* p=0.1 ; * * p=0.05$ & $* * * p=0.01$ & & & & \\
\hline
\end{tabular}

Source: Author's computation, 2019

\subsection{Reasons why maize farmers will pay more for public crop insurance}

Reasons for the choice of small holder farmers to insure their farms are shown in Table 8 below. Out of the 264 maize farmers representing about $84 \%$ of the respondents who reported that they are more comfortable with public crop droughtindex insurance, about $29.55 \%$ farmers believe that public insurance is trustworthy than private insurance. This is to say because government is not an individual, it can be trusted than a private body who can just disappear at any time.

Approximately $28.03 \%$ maize farmers are of the view that public insurance is affordable, this is because government always subsidizes the premium for them and therefore they believe that if the premium is high, government will subsidized for farmers. This result is consistent with Chantarat et al. ${ }^{[29]}$ who stated that crop insurance can be sold at farm, district and country level to farmers with support from government in the form of premium subsidies citing China as an example, where in the year 2008, the China central government subsidized crop insurance premiums for farmers and as a result China became the second largest market after USA.

About $10.98 \%$ of farmers are of the view that government belongs to all and therefore an insurance package from the public sector is worth buying, this results confirms Godwin and Smith ${ }^{[30]}$ conclusion that, insurance that helps protects farmers against yield and production losses from climate and multiple sources of risks on their farms has never been successfully offered by the private sector.

Also, about $12.12 \%$ and $7.20 \%$ farmers said public insurance is less risky and always available respectively whiles $6.82 \%$ and $5.30 \%$ believe that public insurance is easily accessible and they just like public insurance respectively. From the above, it can be deduced that, farmers are more willing to pay more for public insurance because government is always in existence and therefore it will be safer to be with the public sector than to risk on a private company or individual who is more likely to deceive them and relocate or disappear with their investment.

This means that farmers are much concern about trust even though they are interested in insuring their farms against climate change effects and therefore if insurance is not implemented very well it can be seen as a risk to farmers instead of a remedy when the issue of trust is not clearly seen by farmers. 
Table 8. Reasons for preferred insurance source

\begin{tabular}{ccc}
\hline Why farmers will pay more for public insurance & Frequency & Percent \\
\hline Affordable & 74 & 28.03 \\
Always available & 19 & 7.20 \\
Easily accessible & 18 & 6.82 \\
Government is for all & 29 & 10.98 \\
Just like it & 14 & 5.30 \\
Less risky & 32 & 12.12 \\
Trustworthy & 78 & 29.55 \\
Total & 264 & 100 \\
\hline
\end{tabular}

\section{Conclusion}

From the study results, it's very clear that climate change has an effect in every part of northern Ghana where a large majority of the people are small scale farmers and depend solely on climate and natural resources for their farming activities. Climate change is therefore a worrying problem for farmers and has to be effectively mitigated. Obviously, climate change will cause greater climate uncertainties and its effects will continue to deteriorate. Climate change deliberations have to be carried out throughout the farming communities to solve the problem. Most of the respondents declared that crop index insurance is a production risk management tool that can be used to combat the negative effects of climate change on their farms and livelihood as a whole. The study concluded that, the most preferred crop insurance package is the public insurance and government subsidy as the highest rank coping strategy. Therefore government and its development partners must invest in agricultural modernization including crop insurance. It was then recommended that government plays a very significant role to encourage participation by farmers to effectively mitigate against climate change.

\section{References}

[1] Ramiro Iturrioz. Agricultural Insurance. Non-bank financial institutions group. Global capital markets development department, financial and private sector development vice presidency. Primer series on insurance issue 12, November 2009. The World Bank. 2009.

[2] Intergovernmental Panel on Climate Change (IPCC). Summary for policymakers. In Climate Change 2007: Impacts, Adaptation and Vulnerability. Contribution of working group II to the fourth assessment report of the intergovernmental panel on climate change, M.L. Parry, and others, eds. Cambridge: Cambridge University Press; 2007.

[3] Rosegrant, M.W., Cai, X., Cline, S.A. World water and food to 2025: Dealing with scarcity. IFPRI-2020 Vision / International Water. 2002.

[4] Mojarradi, G.R., Zamani, G.H., Zarafshan, K. Analysis of factors influencing farmers' attitudes toward private crop insurer using path analysis. American-Eurasian Journal of Agriculture and Environmental Science. 2008; 3(2): 247252.

[5] The World Bank. Agriculture and Rural Development Department. Managing Agricultural Production Risk Innovations in Developing Countries. 2005.

[6] Agricultural Insurance Company of India Limited (AICI). Crop Insurance in India. 2013.

[7] Carter, M., Janvry, A. de, Sadoulet, E., Sarris, A. Index-based weather insurance for developing countries: A review of evidence and a set of propositions for up-scaling. Fondation Pour Les Études et Recherches Sur Le Développement International, FERDI Working Paper No. 111. 2014. Available from: http://www.ferdi.fr/sites/www.ferdi.fr/files/ publication/fichiers/wp111_index_insurance_web_0.pdf.

[8] Janzen, S. A., Carter M. R. After the drought: The impact of micro-insurance on consumption smoothing and assets protection. 2013 NBER Working Paper No. 19702. 2013.

[9] Singh, G. Crop insurance in India: Indian institute of management ahmedabad-380 015, India, W.P. No. 2010-06-01. 2010.

[10] GAIP Newsletter Quarter 2. 2013. Available from: http://www.gaip-info.com/wp content/uploads/GAIP_NEWS_ Issue_June20131.pdf.

[11] Likert, R. A technique for the measurement of attitudes. Archives of Psychology. 1932; 22(140): 1-55. 
[12] Clason, D. L., Dormody, T. J. Analyzing data measured by individual Likert-type items. 1994.

[13] Lawal, B. Categorical data analysis with SAS and SPSS Application. New Jersey: Lawrence Erlbaum associates, Publishers; 2003. p.353-411.

[14] Pennings, J.M.E, Garcia, P. Measuring producers' risk preferences: A global riskattitude construct. American Journal of Agricultural Economics. 2001; 83(4): 993-1009.

[15] Ayinde, O. E., Muchie M., Omotesh O. A, Ayinde, K., Adewumi, O. Multi-risk model of small-scale agricultural entrepreneurs in central part of Nigeria. International Journal of Academic Research in Economics and Management Sciences. 2012; 1(2).

[16] Maddala, G. S. Limited Dependent and Qualitative Variables in Econometrics. Cambridge: Cambridge University Press; 1983.

[17] Maddala, G. S. Limited dependent and qualitative variables in econometrics. Washington, D.C. IFPRI, Cambridge Management book. Cambridge University Press; 1990.

[18] Babcock, B. A, Chaherli, N. M., Lakshminariayam, P. G. Programme participartion and farm-level. Adoption of Conservation Tillage: Estimates from a Multinomial Logit model Working paper 95-WP 136, Centre for Agricultural and Rural Development. Ames, Iowa: Iowa State University; 1995.

[19] Kimhi, A. Participation of farm owners in farm and off-farm work including the option of full-tine off-farm work. Journal of Agricultural Economics. 1994; 45(2): 232-239.

[20] Greene, W. H. Econometric Analysis. Macmillan. 1993.

[21] Hill, M.A. Female labor force participation in developing and developed countries: Consideration of the informal sector. Review of Econometric and Statistics. 1983; 63(3): 459-468.

[22] IFAD and WFP. Weather index-based insurance in agricultural development a technical guide international fund for agricultural development. World Food Program. 2010.

[23] Bhende, M. J. Flow of credit to small and marginal farmers: A case study of Karnataka. Agricultural Development and Rural transformation unit, ISEC, Bangalore, Ministry of Agriculture, Government of India, New Delhi. 2002.

[24] Wenner, M., Arias, D. Agricultural insurance in Latin America: Where are we? Paving the way forward for rural finance: An international conference on best practices. Agriculture for Development. Inter-American Development Bank. Washington, DC; 2003.

[25] Diaz Nieto, J., Cook, S., Lundy, M., Fisher, M., Sanchez, D., Guevara, E. A system of drought insurance for poverty alleviation in rural areas: The feasibility of practical method of drought insurance that is self-sustaining and ready for use by poor farmers, NGOs or other development organizations. Colombia, South America: Centro Internacional De Agricultura Tropical (CIAT); 2006.

[26] Asrat, P., Belay, K., Hamito, D. Determinants of farmers' willingness to pay for soil conservation practices in the southeastern highlands of Ethiopia. Land Degradation and Development. 2004; 15: 423-438.

[27] Faye, I., K. Deininger. Do new delivery systems improve extension access? Evidence from Rural Uganda. Paper presented at the American Agricultural Economics Association Annual Meeting, July 24-27, Providence, RI, US. 2005.

[28] Karbasi AR, Kambozia N. A study of factors affecting demand for agricultural production insurance in Sistan and Balochestan province. Eqtesad-E Keshavarzi and Towse'e. 2003; 11(41-42): 167-186.

[29] Chantarat S., C. B. Barrett, A. G. Mude, C. G. Turvey. Using weather index insurance to improve drought response for famine prevention. American journal of Agricultural Economics. 2007; 89(5): 1262-1268.

[30] Godwin B. K., Smith V. H. Private and public roles in providing Agricultural insurance in the United States in Jeffrey Brown, editor, public and private roles corporation, Kansas State University. 2009. 